ISSN 1392-3196 / e-ISSN 2335-8947

Zemdirbyste-Agriculture, vol. 102, No. 1 (2015), p. 115-118

DOI 10.13080/z-a.2015.102.015

\title{
Redroot pigweed as a host for Alternaria alternata - the causal agent of Alternaria leaf blight in potato
}

\author{
Stanisław MAZUR, Halina KURZAWIŃSKA, Małgorzata NADZIAKIEWICZ, \\ Jacek NAWROCKI \\ University of Agriculture \\ 31-425 Kraków, Poland \\ E-mail: smazur@ogr.ur.krakow.pl
}

\begin{abstract}
The aim of the study was to establish whether the redroot pigweed (Amaranthus retroflexus L.), which is a common weed in potato crops can be a source of Alternaria alternata, the causal agent of Alternaria leaf blight, and to determine the genetic diversity of isolates of this pathogen infecting the weed and the potato cultivar tested. With the $A$. alternata isolates selected for genetic testing, homosporous cultures were obtained, from which DNA (deoxyribonucleic acid) was subsequently isolated. The genetic diversity of $A$. alternata isolates was determined by the RAPD-PCR (random amplification of polymorphic-polymerase chain reaction) method. Based on the results obtained, it was found that the dominant fungi present on the diseased leaves of both potato and pigweed plants were: Alternaria alternata, A. solani, Cladosporium cladosporioides, C. herbarum, Epicoccum purpurascens and Fusarium sambucinum. Presence of A. alternata as a dominant fungus on redroot pigweed suggests that if weed infestation is extensive, the pathogen is very likely to spread and its population to increase.
\end{abstract}

Key words: Alternaria alternata, Amaranthus retroflexus, Solanum tuberosum.

\section{Introduction}

In spite of the decrease in the potato cultivation area, the production still has great economic weight (Kurzawińska, Mazur, 2008). One of the most important pathogens of potato, besides Phytophthora infestans (Mont de Bary), is Alternaria alternata (Fr.) Keissler. This fungus, along with another species of the genus Alternaria - A. solani (Sorauer), causes Alternaria leaf blight in potato, which is considered by many authors to be the most serious disease destroying the assimilation surface of plants. The disease is common in all areas of potato cultivation (Johnson et al., 2008, Kurzawińska, Mazur, 2009). The knowledge of soil environment where plants grow plays a considerable role in providing its advantageous features to assure satisfactory health state of plants, which is beneficial to increase the yield (Kurzawińska, 2006). The disease has become particularly harmful because the existing weather conditions are favourable for its development and the early onset of the disease causes higher yield losses. In Poland, the first symptoms of the disease have been observed on average 55-70 days after planting, which means that they appear most often in June, in particular in the second and third decade of the month (Kapsa, Osowski, 2007). According to Treikale et al. (2008), the resulting yield losses range from $6 \%$ to $45 \%$. Weeds often found in potato crops can be hosts for certain species of fungi of the genus Alternaria. Among those weeds is the redroot pigweed (Amaranthus retroflexus L.) (Montazeri et al., 2005;
Pusz, 2009; Uremis et al., 2009; Kahramanoglu, Uygur, 2010; Reza Haj Seyed Hadi, Noormohamadi, 2012; Kahramanoglu, 2014). An attempt was therefore made to establish whether the plants of pigweed occurring in potato crops can be a source of $A$. alternata, the causal agent of Alternaria leaf blight, and to determine the genetic diversity of the $A$. alternata isolates infecting the weed and the potato tested.

\section{Materials and methods}

A three-year field experiment was conducted on the potato (Solanum tuberosum L.) cultivar 'Vineta N' at the Agricultural University's Experimental Research Station in Kraków-Mydlniki in 2009-2011. The leaves of this cultivar are very sensitive and quite susceptible to late blight and features good storage durability and moderate resistance to mechanical damage (Eremeev et al., 2006). Winter wheat was used as a forecrop. Manure at a dose of $30 \mathrm{t} \mathrm{ha}^{-1}$, triple superphosphate $46 \% \mathrm{P}_{2} \mathrm{O}_{5}\left(80 \mathrm{~kg} \mathrm{ha}^{-1}\right)$ and potassium chloride $60 \% \mathrm{~K}_{2} \mathrm{O}\left(170 \mathrm{~kg} \mathrm{ha}^{-1}\right)$ were applied in the autumn. Nitro chalk $27 \% \mathrm{~N}$ at $200 \mathrm{~kg} \mathrm{ha}^{-1}$ was applied before planting in the spring. The experiment was set up spacing $62.5 \mathrm{~cm}$ between rows in April (24 04 2009, 2304 2010, 2204 2011). After ridging of potatoes, spraying was carried out as recommended with the herbicide Sencor 70 WG (a.i. metribuzin). Treatments were used in accordance with the standard agricultural practices. 
Roundish brown spots, $2-5 \mathrm{~mm}$ in diameter, were found on the surface of the leaves of the potato and pigweed plants. Small fragments of the leaves showing obvious disease symptoms were selected for mycological tests. They were surface-disinfected with $70 \%$ ethanol, washed twice in sterile distilled water, dried with filter paper, and plated on the PDA (potato dextrose agar) medium. After an incubation period of 4-7 days at $22^{\circ} \mathrm{C}$, the grown colonies were split off onto slants also containing the PDA medium. After development of the fungal isolates on the slants and macro- and microscopic examinations, representatives of the communities were selected. These isolates were inoculated into suitable media and identified with the help of mycological keys and monographs (Dugan, 2006; Klaus et al., 2008). In the characterization of the fungal communities from the leaves of potato and pigweed plants they were classified as: dominant (the most numerous), influential (moderately numerous) and accessory (not numerous) fungi. The criteria, adopted from Kowalik (2013), were based on the percentage of fungi in the entire community: $>5 \%-$ dominant, $1-5 \%$ - influential, $<1 \%$ - accessory fungi.

The Alternaria alternata isolates selected for genetic testing were used to produce homosporous cultures, from which DNA (deoxyribonucleic acid) was subsequently extracted. Extraction of genomic DNA from the isolates of the pathogen was carried out by the CTAB (cetyltrimethylammonium bromide) method (Gardes, Bruns, 1993).

\section{Results and discussion}

Necrotic spots of the tested plants were colonized by a population of 18 species of fungi (Tables 1-2). The dominant species in all experimental years in the communities of fungi isolated from the leaves

Table 1. Quantitative composition of the fungi isolated from potato leaves

\begin{tabular}{|c|c|c|c|c|c|c|c|c|}
\hline \multirow{2}{*}{ Species of fungi } & \multicolumn{4}{|c|}{ Number of isolates } & \multicolumn{4}{|c|}{ Percentage of isolates } \\
\hline & 2009 & 2010 & 2011 & Total & 2009 & 2010 & 2011 & Average \\
\hline Acremonium roseum Petch & 4 & 7 & 6 & 17 & 2.0 & 3.3 & 3.3 & 2.8 \\
\hline Alternaria alternata (Fr.) Keissl. & 57 & 43 & 50 & 150 & 28.2 & 20.4 & 27.2 & 25.1 \\
\hline Alternaria solani Sorauer & 31 & 36 & 27 & 94 & 15.3 & 17.1 & 14.7 & 15.7 \\
\hline Aspergillus spp. & 0 & 0 & 0 & 0 & 0.0 & 0.0 & 0.0 & 0.0 \\
\hline Botrytis cinerea Pers. & 6 & 9 & 7 & 22 & 3.0 & 4.3 & 3.8 & 3.7 \\
\hline Chaetomium indicum Corda & 0 & 0 & 0 & 0 & 0.0 & 0.0 & 0.0 & 0.0 \\
\hline Cladosporium cladosporioides (Fresen.) G.A. de Vries & 21 & 27 & 20 & 68 & 10.4 & 12.8 & 10.9 & 11.4 \\
\hline Cladosporium herbarum (Pers.) Link ex Gray & 22 & 29 & 24 & 75 & 10.9 & 13.7 & 13.0 & 12.6 \\
\hline Colletotrichum coccodes (Wallr.) Hughes & 5 & 4 & 4 & 13 & 2.5 & 1.9 & 2.2 & 2.2 \\
\hline Epicoccum nigrum Link. & 11 & 14 & 9 & 34 & 5.4 & 6.6 & 4.9 & 5.7 \\
\hline Fusarium coeruleum (Saccardo) Booth & 6 & 9 & 6 & 21 & 3.0 & 4.3 & 3.3 & 3.5 \\
\hline Fusarium sambucinum Fuckel & 10 & 16 & 7 & 33 & 5.0 & 7.6 & 3.8 & 5.5 \\
\hline Phoma eupyrena Sacc. & 7 & 4 & 6 & 17 & 3.5 & 1.9 & 3.3 & 2.8 \\
\hline Sordaria fimicola Rob. & 4 & 2 & 3 & 9 & 2.0 & 0.9 & 1.6 & 1.5 \\
\hline Stemphylium botryosum Wallroth & 5 & 3 & 2 & 10 & 2.5 & 1.4 & 1.1 & 1.7 \\
\hline Trichoderma viride Pers. ex Gray & 5 & 3 & 5 & 13 & 2.5 & 1.4 & 2.7 & 2.2 \\
\hline Trichothecium roseum Link & 6 & 4 & 5 & 15 & 3.0 & 1.9 & 2.7 & 2.5 \\
\hline Ulocladium botrytis Preuss & 2 & 1 & 3 & 6 & 1.0 & 0.5 & 1.6 & 1.0 \\
\hline Overall & 202 & 211 & 184 & 597 & 100.0 & 100.0 & 100.0 & 100.0 \\
\hline
\end{tabular}

Table 2. Quantitative composition of the fungi isolated from redroot pigweed leaves

\begin{tabular}{|c|c|c|c|c|c|c|c|c|}
\hline \multirow{2}{*}{ Species of fungi } & \multicolumn{4}{|c|}{ Number of isolates } & \multicolumn{4}{|c|}{ Percentage of isolates } \\
\hline & 2009 & 2010 & 2011 & Total & 2009 & 2010 & 2011 & Average \\
\hline Acremonium roseum Petch & 3 & 2 & 2 & 7 & 2.9 & 2.7 & 2.2 & 2.6 \\
\hline Alternaria alternata (Fr.) Keissl. & 21 & 17 & 20 & 58 & 20.0 & 23.0 & 22.2 & 21.6 \\
\hline Alternaria solani Sorauer & 14 & 10 & 12 & 36 & 13.3 & 13.5 & 13.3 & 13.4 \\
\hline Aspergillus spp. & 2 & 2 & 1 & 5 & 1.9 & 2.7 & 1.1 & 1.9 \\
\hline Botrytis cinerea Pers. & 5 & 3 & 5 & 13 & 4.8 & 4.1 & 5.6 & 4.8 \\
\hline Chaetomium indicum Corda & 2 & 1 & 2 & 5 & 1.9 & 1.4 & 2.2 & 1.9 \\
\hline Cladosporium cladosporioides (Fresen.) G.A. de Vries & 19 & 13 & 14 & 46 & 18.1 & 17.6 & 15.6 & 17.1 \\
\hline Cladosporium herbarum (Pers.) Link ex Gray & 9 & 7 & 7 & 23 & 8.6 & 9.5 & 7.8 & 8.6 \\
\hline Colletotrichum coccodes (Wallr.) Hughes & 0 & 0 & 0 & 0 & 0.0 & 0.0 & 0.0 & 0.0 \\
\hline Epicoccum nigrum Link. & 9 & 7 & 9 & 25 & 8.6 & 9.5 & 10.0 & 9.3 \\
\hline Fusarium coeruleum (Saccardo) Booth & 2 & 0 & 0 & 2 & 1.9 & 0.0 & 0.0 & 0.7 \\
\hline Fusarium sambucinum Fuckel & 7 & 6 & 7 & 20 & 6.7 & 8.1 & 7.8 & 7.4 \\
\hline Phoma eupyrena Sacc. & 0 & 0 & 0 & 0 & 0.0 & 0.0 & 0.0 & 0.0 \\
\hline Sordaria fimicola Rob. & 3 & 2 & 4 & 9 & 2.9 & 2.7 & 4.4 & 3.3 \\
\hline Stemphylium botryosum Wallroth & 0 & 0 & 0 & 0 & 0.0 & 0.0 & 0.0 & 0.0 \\
\hline Trichoderma viride Pers. ex Gray & 2 & 0 & 1 & 3 & 1.9 & 0.0 & 1.1 & 1.1 \\
\hline Trichothecium roseum Link & 5 & 3 & 4 & 12 & 4.8 & 4.1 & 4.4 & 4.5 \\
\hline Ulocladium botrytis Preuss & 2 & 1 & 2 & 5 & 1.9 & 1.4 & 2.2 & 1.9 \\
\hline Overall & 105 & 74 & 90 & 269 & 100.0 & 100.0 & 100.0 & 100.0 \\
\hline
\end{tabular}


of both potato and pigweed plants were: Alternaria alternata (from $20.4 \%$ to $28.2 \%$ of isolates of potato and from $20.0 \%$ to $23.0 \%$ of isolates of pigweed), A. solani (from $14.7 \%$ to $17.1 \%$ of isolates of potato and from $13.3 \%$ to $13.5 \%$ of isolates of pigweed), Cladosporium cladosporioides (from $10.4 \%$ to $12.8 \%$ of isolates of potato and from $15.6 \%$ to $18.1 \%$ of isolates of pigweed), C. herbarum (from $10.9 \%$ to $13.7 \%$ of isolates of potato and from $7.8 \%$ to $9.5 \%$ of isolates of pigweed).

The most frequent species in all years included also the fungi Epicoccum nigrum and Fusarium sambucinum occurring in much smaller numbers from $5.5 \%$ to $9.3 \%$. Other species of the isolated fungi

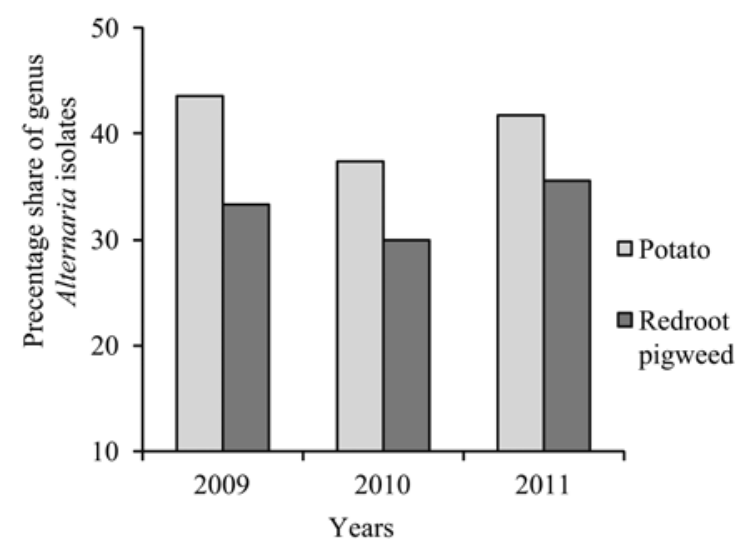

Figure 1. Percentage share of genus Alternaria isolated from leaves of potato and redroot pigweed in 20092011
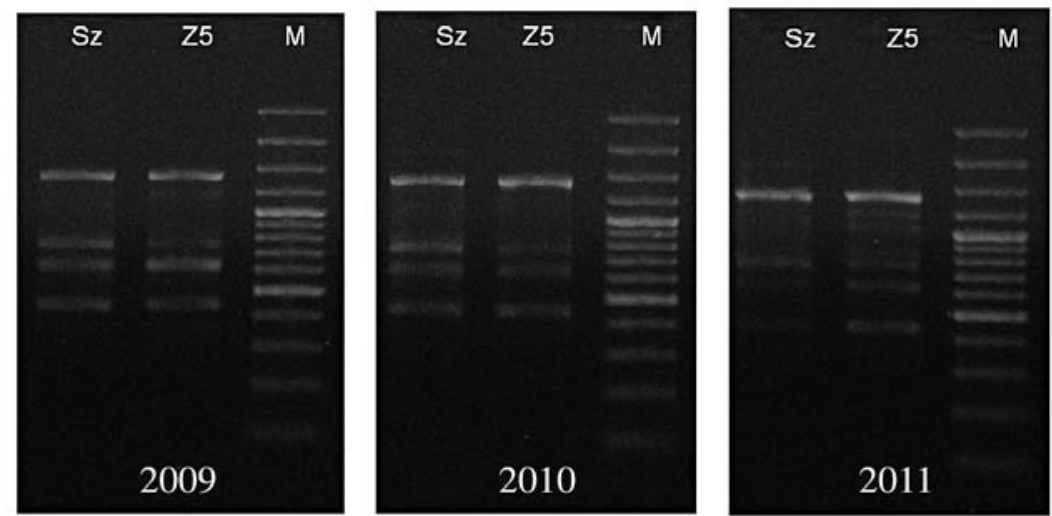

Figure 2. Image of the electrophoretic mobility of the DNA of Alternaria alternata isolated from the redroot pigweed (Sz), potato (Z5) and markers (M) in 2009-2011

\section{Conclusions}

1. The dominant fungi present on the diseased leaves of both potato and redroot pigweed plants were: Alternaria alternata, A. solani, Cladosporium cladosporioides, C. herbarum, Epicoccum nigrum and Fusarium sambucinum. The leaves of the tested plants were colonized to the largest extent by Alternaria alternata.

2. The similarities between $A$. alternata isolates obtained from potato plants and those obtained from pigweed plants signify the importance of weeds as a source of the pathogen for potato crops.

Received 14082014 Accepted 15012015 constituted from $1.0 \%$ to $4.3 \%$. It needs to be emphasized that the leaves of the potato and pigweed plants tested were colonized to the greatest extent by $A$. alternata.

Potato leaf colonization by fungi genus Alternaria in all experimental years was higher compared to that of redroot pigweed leaves (Fig. 1).

The occurrence of Alternaria blight depends on a complex of factors (Iglesias et al., 2007; Hubballi et al., 2010). According to Johnson et al. (2008) and Kapsa (2008), the development of epiphytoses of the disease is determined by, among other things, the average temperature in July-August above $18^{\circ} \mathrm{C}$, relative air humidity up to $80 \%$, heavy showers, overnight dew, and sandy soils.

Studies of the genus Alternata are increasingly based on genetic analyses. Molecular biology methods make it possible to explore the genetic relationships between isolates or groups of isolates, which cannot be determined by conventional methods (Gherbawy, 2005; Kale et al., 2012). Based on the results of the analyses presented here, it was found that in three cases there was high similarity between the DNA of the pathogen isolated from potato plants and that isolated from pigweed plants (Fig. 2). Evidence of the dominance of A. alternata on redroot pigweed, which is a common weed in potato crops, suggests that with extensive weed infestation an increase in the size of this pathogen's population may occur and the pathogen is likely to spread. 
Hubballi M., Nakkeeran S., Raguchander T., Anand T., Samiyappan R. 2010. Effect of environmental conditions on growth of Alternaria alternata causing leaf blight of noni. World Journal of Agricultural Sciences, 6 (2): 171-177

Iglesias I., Rodriguez-Rajo F. J, Mendez J. 2007. Evaluation of the different Alternaria prediction models on a potato crop in A Limia (NW of Spain). Aerobiologia, 23: 27-34 http://dx.doi.org/10.1007/s10453-006-9045-8

Johnson D., Powelson M., Rowe R., Stevenson W., Thornton R. 2008. Potato health management. The American Phytopathological Society, St. Paul, USA, $261 \mathrm{p}$.

Kahramanoglu I. 2014. Assessment of pre-planting Pendimethalin's minimum dose on redroot pigweed (Amaranthus retroflexus L.). International Journal of Agricultural Sciences, 4 (6): 210-213

Kahramanoglu I., Uygur F. 2010. The effects of reduced doses and application timing of metribuzin on redroot pigweed (Amaranthus retroflexus L.) and wild mustard (Sinapis arvensis L.), Turkish Journal of Agriculture and Forestry, 34: $467-474$

Kale S., Pardeshi V., Gurjar G., Gupta V., Gohokar R., Ghorpade P., Kadoo N. 2012. Inter-simple sequence repeat markers reveal high genetic diversity among isolates of Indian origin Alternaria alternata. Journal of Mycology and Plant Pathology, 42 (2): 194-200

Kapsa J. 2008. Important threats in potato production and integrated pathogen/pest management. Potato Research, 51: $385-401$ http://dx.doi.org/10.1007/s11540-008-9114-1

Kapsa J., Osowski J. 2007. Evaluation of performance of Burkard trap in identification of Alternaria species infecting potato crops. Proceedings of $10^{\text {th }}$ workshop of European network for development of an integrated control strategy of potato late blight. Bologna, Italy, p. 183-188

Klaus H., Domsch W., Gams W., Anderson T. 2008. Compendium of soil fungi ( $2^{\text {nd }}$ ed.). St. Paul, USA, $672 \mathrm{p}$.
Kowalik M. 2013. Diversity of fungi colonizing and damaging leaves of pontic azalea Azalea pontica. Acta Mycologica, 48 (2): $227-236$

http://dx.doi.org/10.5586/am.2013.024

Kurzawińska H. 2006. An interaction of potato crop soil fungi population on fungi responsible for tuber superficial diseases. Journal of Plant Protection Research, 46 (4): 339-346

Kurzawińska H., Mazur S. 2008. The effect of chitosan and Pythium oligandrum used in production of potato tubers against late blight and soft rot. Progress on Chemistry and Application of Chitin and its Derivatives, 13: 117-123

Kurzawińska H., Mazur S. 2009. The evaluation of Pythium oligandrum and chitosan in control of Phytophthora infestans (Mont.) de Bary on potato plants. Folia Horticulture, 21 (2): 13-23

Montazeri M., Graves M., Pei M., Ruiz C. 2005. An analysis of genetic diversity in hyphal tip isolates of promisisng mycoherbicide Alternarai alternata. Iranian Journal of Weed Science, 1: 51-65

Pusz W. 2009. Morpho-physiological and molecular analyses of Alternaria alternata isolated from seeds of Amaranthus. Phytopathologia 54: 5-14

Reza Haj Seyed Hadi M., Noormohamadi G. 2012. Competitive effects of redroot pigweed (Amaranthus retroflexus) and lambsquarter (Chenopodium album) on potato. Scientific Research and Essays, 7 (31): 2781-2787

Treikale O., Rude O., Pugacheva J., Lazareva L. 2008. The developement of Alternaria slolani SOR. on potatoes cultivated in monoculture. Zemdirbyste-Agriculture, 95 (3): 202-208

Uremis I., Caliskan M., Uludag A., Caliskan S. 2009. Weed management in early season potato production in the Mediterranean conditions of Turkey. Bulgarian Journal of Agricultural Science, 15 (5): 423-434

ISSN 1392-3196 / e-ISSN 2335-8947

Zemdirbyste-Agriculture, vol. 102, No. 1 (2015), p. 115-118

DOI $10.13080 /$ z-a.2015.102.015

\title{
Šiurkštusis burnotis - bulvių lapų sausligès sukèlėjo Alternaria alternata augalas šeimininkas
}

\author{
S. Mazur, H. Kurzawińska, M. Nadziakiewicz, J. Nawrocki \\ Krokuvos žemès ūkio universitetas, Lenkija
}

\section{Santrauka}

Tyrimo tikslas - nustatyti, ar šiurkštusis burnotis (Amaranthus retroflexus L.), kuris yra bulvių pasèliuose paplitusi piktžolè, gali būti Alternaria alternata, bulvių lapų sausligès sukèlèjo, šaltinis, ir nustatyti šio patogeno, infekuojančio ir piktžolę, ir tirtos veislès bulves, genetinę įvairovę. A. alternata izoliatus surinkus genetiniam tyrimui buvo gautos homosporinès kultūros, iš kuriu buvo išskirta DNR (deoksiribonukleo rūgštis). Genetinè A. alternata izoliatų ịvairovè buvo nustatyta AAPD-PGR (atsitiktinai amplifikuotų polimorfinès DNR polimerazès grandininès reakcijos) metodu. Remiantis tyrimo rezultatais nustatyta, kad ant šiurkščiojo burnočio ir bulvių ligos pažeistų lapų aptikti vyraujantys grybai buvo šie: Alternaria alternata, A. solani, Cladosporium cladosporioides, C. herbarum, Epicoccum purpurascens ir Fusarium sambucinum. A. alternata dominavimas ant šiurkščiojo burnočio rodo, kad jeigu piktžolètumas yra didelis, šis grybas gali išplisti, o jo populiacija padidèti.

Reikšminiai žodžiai: Alternaria alternata, Amaranthus retroflexus, Solanum tuberosum. 